\title{
Antes das grades: perfis e dinâmicas criminais de mulheres presas em Minas Gerais
}

Recebido: 29.10.20 Aprovado: 08.07 .21

\author{
Ludmila Ribeiro (http://orcid.org/0000-0003-4304-2254), \\ Universidade Federal de Minas Gerais (UFMG), Belo Horizonte, MG, Brasil'. \\ Natalia Martino (https://orcid.org/0000-0001-5377-2993), \\ Universidade Federal de Minas Gerais (UFMG), Belo Horizonte, MG, Brasil".
}

Thais Lemos Duarte (https://orcid.org/0000-0002-9149-7387), Universidade Federal de Minas Gerais (UFMG), Belo Horizonte, MG, Brasil"'."

\author{
I. Ludmila Ribeiro \\ é doutora em \\ sociologia, professora \\ no Departamento \\ de Sociologia e \\ pesquisadora no \\ Centro de Estudos \\ de Criminalidade e \\ Segurança Pública \\ (Crisp), ambos na \\ UFMG. \\ <lmlr@ufmg.br>.
}

II. Natalia Martino é doutoranda em ciência política e pesquisadora no Centro de Estudos de Criminalidade e Segurança Pública, ambos na UFMG. <natymartino@ gmail.com> pesquisa qualitativa e quantitativa com custodiadas por tráfico de drogas de unidades prisionais de Minas Gerais, analisamos em que medida esse enquadramento acadêmico condiz com os relatos das mulheres sobre suas trajetórias. De acordo com as presas, há uma convergência entre o campo de estudo da criminalidade feminina e o tratamento fornecido pelos atores do sistema de Justiça Criminal à questão. Essa homogeneidade das ideias, porém, não é suficiente para abarcar a diversidade de pertencimentos das mulheres aos mercados ilegais de drogas.

Palavras-chave: Criminalidade feminina. Tráfico de drogas. Papéis de gênero. "Amor bandido". Sistema de Justiça Criminal.

\section{Before the bars:}

\section{Profiles and criminal dynamics of women prisoners in Minas Gerais}

Abstract: The increase in the number of women prisoners in Brazil in the last decade, especially for drug trafficking, has led to the proliferation of studies on crime and female incarceration. A major part of these works presents narratives linked to traditional gender roles to explain the involvement of women in illegal networks, the expression "bandit love is the key to jail" being a synthesis of this understanding. Based on a qualitative and quantitative research with custodians for drug trafficking in Minas Gerais, we analyzed the extent to which this framework is consistent with women's reports on their trajectories. According to the inmates, there is a convergence between the field of study on female crime and the treatment provided by the actors of the criminal justice
III. Thais Lemos

Duarte

é doutora em

ciências sociais, pesquisadora de pós-doutorado em sociologia e pesquisadora do de Criminalidade e Segurança Pública, UFMG.

$<$ thais-duarte@ hotmail.com>. Centro de Estudos 
system to this issue. This homogeneity of ideas, however, is not enough to encompass the diversity of women's belongings to the illegal drug markets.

Keywords: Female crime. Drug trafficking. Gender roles. "Bandit love". Criminal justice system.

\section{Apresentação}

N as últimas décadas, as mulheres "criminosas" têm recebido maior atenção por parte dos estudos voltados ao funcionamento do sistema de Justiça Criminal (Azevedo \& Sinhoretto, 2018) e a descortinar as experiências femininas atrás das grades (Lourenço \& Alvarez, 2018). Todavia, tais análises tendem a enquadrar as mulheres em relações de subordinação aos homens, seja como cuidadoras dos presos (Silvestre, 2012), seja como mulas ou guardadoras de drogas (Valença \& Castro, 2018). Poucas são as pesquisas que analisam as escolhas pessoais, como discutido por Ludmila Carneiro (2015), Mônica Cortina (2015) e Mariana Barcinski (2009). Cabe questionar, portanto, se, de fato, os homens têm tamanho papel de destaque na vida delas ou se esse tipo de olhar deriva de vieses acadêmicos ou de órgãos relacionados à pauta penal.

De fato, chama atenção o aumento progressivo de mulheres privadas de liberdade (Carneiro, 2015): só entre 2006 e 2016 esse percentual cresceu 455\% no Brasil, sendo a maioria delas autuada por tráfico de drogas (Ministério da Justiça, 2017). Se, em 2000, havia 5,6 mulheres presas para cada 100 mil mulheres, em junho de 2017 havia 35,6 para cada 100 mil (Ministério da Justiça, 2017). Enquanto os homens encarcerados por tráfico de drogas somam 30\% da população carcerária masculina, as mulheres superam os $60 \%$ da feminina, indicando que esse delito é o principal motivo para o encarceramento delas (Ministério da Justiça, 2017). Em dezembro de 2019, o país contava com mais de 42 mil custodiadas (World Prison, 2020).

Neste contexto, a proposta deste artigo é analisar traços da trajetória criminal de presas por tráfico de drogas em duas unidades penitenciárias de Minas Gerais: o Complexo Penitenciário Feminino Estevão Pinto, em Belo Horizonte, e o Centro de Referência à Gestante Privada de Liberdade, em Vespasiano. Em específico, procuramos compreender as consonâncias e as dissonâncias entre o apontado por mulheres presas sobre as dinâmicas criminais por elas empreendidas em relação ao enquadramento dado a essas práticas pela literatura especializada e pelo sistema de Justiça Criminal. Para tanto, iremos analisar os relatos das custodiadas no que diz respeito às redes ilícitas relacionadas ao varejo de drogas que elas compunham - ou não -, bem como o contexto de suas prisões e de seus julgamentos. 
O escrutínio desses depoimentos evidencia que as mulheres mantêm uma variedade de vínculos com os mercados ilegais, o que contrasta com o tratamento monolítico normalmente fornecido a elas. Para entender como a academia e o sistema de Justiça Criminal constrói a narrativa do "amor bandido como chave de cadeia", ignorando o protagonismo dessas mulheres na construção de sua própria história, na próxima seção apresentaremos um breve apanhado de como classe, gênero e raça se entrecruzam, consubstanciando relações produtoras de dominações e opressões.

\section{Reflexões sobre gênero e dinâmicas criminais}

Abordar a dinâmica criminal feminina necessariamente requer discutir aspectos sociais e econômicos que se mesclam. A ideia de articular relações sociais de sexo e de classe foi proposta na França, ao final dos anos 1970, por Danièle Kergoat (1978) para desvelar, de maneira não mecânica, as práticas sociais de homens e mulheres diante da divisão social do trabalho em sua tripla dimensão: de classe, gênero e raça (Hirata, 2014).

Para Helena Hirata e Danièle Kergoat (2007), o problema do feminismo na França é consequência de o movimento não se atentar às questões de classes social e origem, fazendo com que as mulheres produzissem relações de exploração de suas semelhantes, sob o signo de que precisavam ocupar a vida pública. As mulheres brancas de classe média contratavam as pobres e imigrantes para a realização do trabalho doméstico, o que permitia às mais ricas conjugar as demandas entre cuidado e mercado de trabalho, ainda que às expensas daquelas que sequer conseguiam garantir a sua própria sobrevivência. Tal constatação sublinha a importância de se analisar conjuntamente as dominações estruturais, não contribuindo para sua reprodução.

Por isso, questões relativas à raça, ao gênero, à classe devem ser lidas conjuntamente, já que conferem trajetórias peculiares, em especial às mulheres (Scott, 1995). Donna Haraway (1995), identificando a tendência da ciência de reificação de papéis sociais, propôs a busca da "objetividade corporificada": a construção de um conhecimento científico que não se pretenda transcendental, mas que assuma sua visão segmentada e a torne objetiva ao deixar clara a parcialidade. O que a autora sugere é a adoção de uma visão a partir dos grupos oprimidos, não por romantizar tal perspectiva, mas por saber que esse é o ponto de referência mais comumente apagado nas narrativas sociais hegemônicas. 
Na mesma direção, Sandra Harding (2001) identifica três tradições de estudos feministas:

i. a fenomenológica, concentrada nas experiências das mulheres e nos significados que elas atribuem às vivências;

ii. a socialista, focada nos lugares sociais e econômicos destinados às mulheres;

iii. a culturalista, preocupada com a forma como os discursos sociais modelam a vida das mulheres.

Para a autora, é preciso conjugar essas três perspectivas na produção de um conhecimento não reificante da posição feminina.

Ao conjugar Hirata e Kergoat (2007), Haraway (1995) e Harding (2001), o nosso intento neste trabalho é apresentar uma leitura sobre o lugar ocupado por mulheres negras e pobres (interseccionando classe e raça) a partir dos discursos que elas próprias produziram. Num primeiro plano, destacamos a forma como se estrutura a discriminação social brasileira, que coloca a mulher negra no estrato mais baixo da pirâmide de classe e do prestígio ocupacional. Num segundo momento, problematizamos como essas mulheres têm suas narrativas silenciadas pelo sistema de Justiça Criminal que, ao invés de perguntar-lhes sobre as razões para o envolvimento com o tráfico de drogas, nega-lhes o poder de agência, atribuindo tal escolha a uma determinação masculina.

Para iniciar essa discussão, nos fundamentamos das reflexões de Lélia Gonzalez (2020), importante intelectual e ativista negra de nosso país. Ao analisar o contexto histórico brasileiro, a autora afirmou que o racismo, enquanto articulação ideológica e conjunto de práticas, denota sua eficácia estrutural na divisão racial do trabalho, compartilhada por todas as formações socioeconômicas contemporâneas. Embora boa parte da população brasileira tenha se pautado pelo mito da "democracia racial", proposto por Gilberto Freyre (Schwarcz, 2013), a raça é um dos principais fatores de estruturação do sistema de classes e de prestígio ocupacional. Não à toa, é a população negra que compõe o exército de reserva ou a massa marginal crescente.

Logo, o que opera no país não é apenas uma discriminação efetiva, materializada nas desigualdades econômicas entre as pessoas de diferentes raças. Aciona também representações sociais mentais, que se reforçam e se reproduzem de múltiplas maneiras, institucionalizando um racismo cultural, que leva tanto algozes como vítimas a considerarem natural as pessoas negras desempenharem papéis sociais des- 
valorizados (Gonzalez, 2020). Mais do que isso, entende-se como compreensível e justificável esses indivíduos serem alvos constantes do sistema de Justiça Criminal, como se fossem suspeitos em potencial (Gonzalez \& Hasenbalg, 1982).

Cabe, pois, ao homem negro e pobre o trabalho precarizado e/ou cair nas malhas do controle estatal, sendo objeto de dura repressão. Em geral, seu destino ou é a morte ou é o cumprimento de pena em unidade de privação de liberdade (Gonzalez, 2020). Já a mulher negra vive sob tripla discriminação, pois os estereótipos impulsionados pelo racismo e pelo sexismo aumentam a opressão sobre ela (Ericson, 2020). Ela costuma exercer atividades destinadas ao conforto das classes mais abastadas para somar sua renda doméstica, acrescida da dupla jornada de trabaIho. Longe de ser algo emancipador, esse tipo de tarefa a torna vulnerável ao abuso e ao assédio (hooks, 2020), por isso as mulheres negras são as mais susceptíveis às baixas ocupações no mercado de trabalho ou a se enquadrarem na categoria de "desalentadas" (Ericson, 2020).

A inserção em dinâmicas criminais se apresenta como uma das vias para as muIheres negras e pobres auferirem seu sustento e o de sua família (Carneiro, 2015; Cortina 2015; Barcinski, 2009). Sua caracterização social, como parte de um grupo tradicionalmente visto como "suspeito" pela raça e pelos locais de moradia marcados pela pobreza, as deixa também mais suscetíveis ao enquadramento da Justiça Criminal. No entanto, nem sempre a literatura sobre criminalidade feminina teve esse olhar sobre o problema. Em alguns casos, a apresentação do conhecimento científico como "superior" terminou por inferiorizar os subalternos, reificando lugares tradicionalmente destinados a esses grupos (Alcoff \& Potter, 1993). A seguir, nos aprofundaremos nesse debate, expondo como as pesquisas nacionais retratam a inserção feminina nas redes do tráfico de drogas.

\section{Como a literatura brasileira retrata}

a mulher no tráfico de drogas?

De acordo com Olga Espinoza (2004), a criminologia tendeu, por muito tempo, a analisar apenas os homens em contato com o sistema de Justiça Criminal, ignorando as especificidades das mulheres. O feminismo procurou reverter essa lacuna ao introduzir o olhar de gênero no sistema de punição. Para tanto, foi preciso estudar as muIheres de acordo com a visão de "mundo" delas próprias, o que significa compreendê-las a partir do questionamento da sociedade. Significa também propor políticas que não sejam baseadas na "reabilitação das presas", mas na transformação "das relações sociais de sexo e das instituições que as sustêm" (Espinoza, 2004: 74-75). Infelizmente, poucos foram os avanços ocorridos nesse campo no cenário brasileiro. 
O aprisionamento feminino começou a atrair atenção acadêmica no Brasil apenas nas duas últimas décadas, quando as taxas de encarceramento das mulheres passaram a crescer exponencialmente (Lourenço \& Alvarez, 2018). Pouco sabemos sobre os mecanismos e os padrões que as levam ao cárcere, de modo que a maioria das análises focaliza as condições da privação de liberdade, sem compreender a trajetória pregressa dessas mulheres. Aqui cabe uma breve retomada dessa história.

Quando as primeiras prisões femininas foram inauguradas no Brasil, nos anos 1930, a "perturbação da ordem", categoria que englobava delitos como prostituição e homicídios "passionais", praticados contra maridos, filhos ou outros membros da família, constituíam os desvios que mais encarceravam as mulheres (Angotti \& Salla, 2018). O primeiro tipo aprisionava, em especial, as pobres que precisavam trabalhar no espaço público (Angotti, 2012). Quando privadas de liberdade, ficavam separadas daquelas que tinham cometido homicídio. Em geral, quando uma mulher matava alguém, considerava-se que tinha agido por "loucura" em face até mesmo da própria condição feminina e suas variações hormonais. Por isso, seu crime era visto como menos gravoso (Ratton \& Galvão, 2016), o que justificava a sua separação das demais nas unidades prisionais. Os trabalhos com enfoque histórico tenderam a não se estender para além da década de 1950.

Um lapso entre os anos 1960 e 1970, quando a narrativa sobre os cárceres brasileiros girou em torno das prisões políticas ocasionadas pela ditadura civil-militar, nos dificulta a compreensão de quando e como as detenções femininas começaram a ser acarretadas por crimes contra o patrimônio. Este foi o cenário encontrado por Julita Lemgruber (1999), posto que 60\% das mulheres privadas de liberdade na década de 1980 ali estavam por delitos como roubo, ao passo que $20,8 \%$ tinham sido encarceradas por tráfico de entorpecentes. Se o perfil criminal mudou, essas análises mantiveram a reflexão de que as mulheres costumam ser duplamente punidas quando cometem um delito: primeiro, por terem rompido com uma regra do sistema de Justiça Criminal; segundo, por não atenderem aos papéis de gênero socialmente dominantes.

De fato, historicamente o universo de presas costuma ser expressivamente menor em relação ao de homens. Algumas pesquisas atribuíram tal proporcionalidade a uma maior leniência do sistema de Justiça Criminal em relação às mulheres (Ribeiro \& Lopes, 2019). Não à toa, a partir de entrevistas com custodiadas no Complexo Penitenciário Estevão Pinto, no início dos anos 2000, Ludmila Ribeiro (2003) identificou que as mulheres acreditavam ser "invisíveis" às autoridades policiais. Entretanto, a criminalização dos comportamentos em decorrência do tráfico de drogas mudou radicalmente este cenário (Miyamoto \& Krohling, 2012). Em 2000, pela primeira vez, os crimes relacionados às drogas superaram os delitos contra o patrimônio, sendo 
responsáveis por $56 \%$ das prisões femininas no Brasil (Soares \& Ilgenfritz, 2002). Foi nesse período que o encarceramento feminino começou a crescer proporcionalmente de forma mais rápida do que o masculino (Ministério da Justiça, 2017).

Para entender essa curva ascendente de mulheres em situação de cárcere, é preciso remeter à nova Lei de Drogas (Lei 11.343/2006). A legislação retirou a pena de prisão para usuários e, ainda, tornou o comércio de drogas um crime hediondo (Carneiro, 2015). No entanto, não apresentou formas objetivas de diferenciação entre consumo e venda, de forma que a classificação do ato se pauta, em boa medida, na discricionariedade de agentes de Segurança Pública, notadamente policiais (Valença \& Castro, 2018). Com efeito, pessoas das classes baixas, geralmente negras e pobres, tendem a ser mais enquadradas como traficantes do que outros perfis socioeconômicos (Azevedo \& Sinhoretto, 2018).

Em parte, isso ocorre porque esses grupos mais susceptíveis à criminalização pelo tráfico de drogas vivem em periferias (Carneiro, 2015). De acordo com Maria Ivone Cunha (2018), algumas tecnologias governamentais direcionam os policiais para espaços marginais urbanos, como se apenas nesses territórios o crime pudesse acontecer ou precisasse ser reprimido. No Brasil, o resultado foi a explosão de pessoas privadas de liberdade por crimes relativos às drogas, posto que os policiais tendem a concentrar suas atividades em que, na visão desses profissionais, o comércio de substâncias ilegais ocorre de forma mais visível. As mulheres seriam, assim, aprisionadas no mesmo contexto que os homens.

Acreditamos que foi em razão dessa coincidência do lugar territorial em que homens e mulheres de baixa renda são presos por tráfico de drogas que foi criada a tese sobre a afinidade entre relações emocionais e comerciais. Segundo Cortina (2015: 767), tal coincidência "não se explica somente através da superficial leitura de que foram aliciadas ou influenciadas pelos companheiros e familiares envolvidos com a mercancia ilegal, apesar de tal circunstância de fato existir". O tráfico de drogas é uma escolha pessoal, permitindo que as mulheres componham a renda doméstica juntamente com outros tipos de ocupações (Padovani, 2015). No entanto, mesmo dentro dos networks ilícitos, as mulheres tendem a ocupar as posições inferiores, se dedicando à realização de serviços desvalorizados, ou tarefas associadas ao feminino como cozinhar, limpar, embalar drogas ou realizar pequenas vendas (Carneiro, 2015).

Conclusões dessa natureza resvalam nas narrativas de que o amor bandido é "chave de cadeia" (Helpes, 2014), com efeitos imediatos nos padrões de policiamento e de processamento do sistema de Justiça Criminal (Ribeiro \& Lopes, 2019). Na expectativa de que os homens, se presos, irão pressionar suas mulheres a assumir 
o negócio, os policiais realizam as famosas "batidas" nas residências, com vistas à apreensão de drogas e armas. No sistema prisional, na condição de visitas a homens privados de liberdade, essas mulheres se tornam vítimas de ações vexatórias de revista. Se encarceradas, "provindo dos mesmos bairros, as reclusas chegam à prisão articuladas em teias de interconhecimento combinando laços de parentesco, amizade e vizinhança" (Cunha, 2018: 6). Elas se auxiliam na reorganização de suas vidas, sendo que essa aproximação poderia mesmo facilitar a conexão das presas dentro de networks ilegais (Padovani, 2015).

Rosangela Gonçalves e Josiane Brito (2019) se dedicaram a compreender a inserção de mulheres nas rotinas do grupo criminal Primeiro Comando da Capital (PCC). O coletivo as incorpora em suas atividades e estruturas, mas em funções e papéis associados ao trabalho considerado "leve", "limpo", isto é, realizado sem violência. São atividades que demandam precisão, paciência, cuidado, afeto e altruísmo, de modo que as tarefas atribuídas às mulheres são sempre atreladas a uma concepção de feminilidade, sem retorno financeiro. Cabe a elas atividades circunscritas ao espaço doméstico, como repassar ordens de seus companheiros, cuidar da contabilidade, da organização e do tráfico de drogas.

Lucia Sena (2015), cujo estudo focou as redes do mercado ilegal de entorpecentes em Belo Horizonte, destoa dessas narrativas. Para ela, as mulheres ocupam diferentes posições na hierarquia das redes criminais, das mais baixas às mais altas. Desenvolveriam uma espécie de "funcionalidade moral", não sendo apenas vítimas de características tradicionalmente imputadas às mulheres e consideradas inferiores em relação aos masculinos. Em alguns momentos, as mulheres instrumentalizariam tais atributos para atingir níveis mais elevados na criminalidade. Ou seja, mobilizam predicados socialmente considerados femininos, como passividade e cordialidade, para dissimular seu papel nas redes de tráfico de drogas, o que as garantiria maior lucratividade e menor visibilidade.

A partir dessas reflexões, uma dimensão que nos parece pouco problematizada na literatura, e da qual trataremos nos próximos tópicos, se relaciona ao fato de como as mulheres instrumentalizam a narrativa do "amor bandido como chave de cadeia" para garantir menor reprovação de suas condutas. Argumentamos que as mulheres talvez lancem mão de uma espécie de "funcionalidade moral" (Sena, 2015), com vistas a alcançar menores penas pelo tráfico de drogas. Com isso, elas seriam mais facilmente "desculpadas" da violação de seus papéis de gênero pela prática de um crime. Afinal, o crime só aconteceu porque elas estavam dando vida a um outro papel feminino: o de se sujeitar às demandas e vontades masculinas. 


\section{Aspectos metodológicos}

Os dados analisados neste artigo foram coligidos no âmbito de um projeto de pesquisa desenvolvido entre os anos de 2017 e 2018, realizado com o apoio da Fapemig (APQ 01648-16) e aprovado pelo Comitê de Ética (Caae: 84242418.4.0000.5149). Este estudo compreendeu a coleta de informações quantitativas e qualitativas no Complexo Penitenciário Estevão Pinto e no Centro de Referência à Gestante Privada de Liberdade, ambos localizados na Região Metropolitana de Belo Horizonte.

Minas Gerais é um estado de destaque na temática do encarceramento feminino, abrigando mais de quatro mil presas, o que representa $10 \%$ da população prisional feminina brasileira (Ministério da Justiça, 2017). Do total de presas nos cárceres mineiros, $10 \%$ (ou quase 400 ) estão nas unidades por nós pesquisadas. O Complexo Penitenciário Estevão Pinto é a maior e mais antiga penitenciária para mulheres do estado e uma das mais antigas do Brasil, voltada a distintos tipos de cumprimento de pena (Martino, 2019). Já o Centro de Referência à Gestante Privada de Liberdade é uma unidade materno-infantil inaugurada em 2009 no município de Vespasiano, referência para outras experiências do gênero no Brasil e na América Latina (Chaves \& Araújo, 2020). É a única unidade desse tipo no estado, portanto, recebe todas as mulheres gestantes e lactantes encarceradas em Minas Gerais.

Uma parte da investigação se referiu a um survey realizado com 170 das 396 custodiadas no Complexo Penitenciário Estevão Pinto e 25 das 51 internas do Centro de Referência à Gestante Privada de Liberdade, totalizando 195 questionários ${ }^{1}$. Para a coleta desses dados, as pesquisadoras se dirigiram até as unidades e apresentaram às mulheres os objetivos do estudo. Em seguida, perguntaram se havia interessadas em responder ao formulário e, em caso positivo, iniciaram a entrevista. No Complexo Penitenciário Estevão Pinto, a aplicação dos questionários ocorreu nas celas e em ambientes laborais e, no Centro de Referência à Gestante Privada de Liberdade, nos pátios onde as mulheres passam a maior parte do dia. O instrumento abrangia, entre outros aspectos, questões sobre o perfil das presas, suas características familiares, as dinâmicas empreendidas durante o cometimento do(s) crime(s) que as levaram às unidades penitenciárias, além das condições em que foram presas e julgadas. Especificamente, cerca de $86 \%$ já tinham recebido uma sentença condenatória no momento de realização da pesquisa, ao passo que aproximadamente $14 \%$ aguardavam decisão judicial.

Além do survey, a pesquisa também abrangeu 22 entrevistas semiestruturadas com as custodiadas. Dezesseis foram desenvolvidas com mulheres acusadas ou conde-
1. Data base para cálculo da amostra com base no número de mulheres presas nas unidades: 01 de julho de 2017 (para o Centro de Referência à Gestante Privada de Liberdade) e 01 de fevereiro de 2018 (para a Complexo Penitenciário Estevão Pinto). 
nadas por envolvimento com tráfico de drogas, nove delas da Complexo Penitenciário Estevão Pinto e sete do Centro de Referência à Gestante Privada de Liberdade. As conversas foram travadas a partir de convites realizados nos dias da pesquisa de campo, sendo efetivadas em salas reservadas, sem a presença de terceiros, e com a garantia de anonimato.

Nas próximas seções, procuramos apresentar como as mulheres entrevistadas tematizam seus envolvimentos nas atividades de tráfico de drogas. Para tanto, utilizamos os dados quantitativos e qualitativos coletados. Com vistas à preservação da identidade das mulheres privadas de liberdade, as entrevistadas receberam nomes fictícios, que não guardam qualquer relação com seus nomes reais.

\section{Tráfico e prisão}

Dentre as entrevistadas, 58\% foram enquadradas pelo sistema de Justiça Criminal como traficantes. Ao comparar este grupo com as demais custodiadas, não verificamos qualquer diferença estatisticamente significativa em termos de idade, cor da pele, grau de escolaridade ou existência de filhos fora da prisão. De fato, como pode ser observado na Tabela 1, tanto as presas por tráfico de drogas como por outros crimes são provenientes de estratos socioeconômicos mais baixos, são jovens, negras (pretas e pardas) e estudaram menos de nove anos (equivalente ao ensino fundamental completo). Ainda, a maioria tem filhos fora da prisão.

O perfil das entrevistadas é semelhante ao padrão geral das mulheres presas no Brasil e, também, ao de homens encarcerados (Ministério da Justiça, 2017). Essas similaridades podem ser visualizadas no Gráfico 1, a seguir, que demonstra como, apesar de o grupo entrevistado ter um nível médio de escolaridade um pouco mais alto e ser composto por uma porcentagem menor de pessoas negras, as categorias "ensino fundamental incompleto" e "negros" são predominantes. Isso confirma "a seleção discriminatória do sistema penal, pois submete à prisão mulheres jovens, mães de mais de um filho ou de mais de uma filha" (Cortina, 2015: 777), que poderiam estar trabalhando de forma regular no mercado de drogas, caso esse comércio não fosse criminalizado.

Nas análises subsequentes, focalizaremos apenas as entrevistadas acusadas ou condenadas por tráfico de drogas (106 mulheres), sendo que as demais serão desconsideradas do estudo em razão dos objetivos aqui propostos. Dividiremos o debate empírico a partir de três pontos centrais: $i$. traços das trajetórias e dinâmicas criminais relatadas pelas mulheres; ii. características das detenções que acarretaram a privação de liberdade; e iii. perfis dos julgamentos que levaram às condenações. 
TABELA 1

Perfil das mulheres entrevistadas na Complexo Penitenciário Estevão Pinto

E no Centro de Referência à Gestante Privada de Liberdade,

DE ACORDO COM O CRIME QUE LEVOU AO ENCARCERAMENTO

\begin{tabular}{|c|c|c|c|c|}
\hline \multirow{2}{*}{ Perfil } & \multicolumn{2}{|c|}{ Presa por tráfico } & \multicolumn{2}{|c|}{ Presa por outros crimes } \\
\hline & $\mathrm{N}$ & $\%$ & $\mathrm{~N}$ & $\%$ \\
\hline \multicolumn{5}{|l|}{ Idade } \\
\hline Entre 18 e 29 anos & 56 & $52,8 \%$ & 34 & $38,2 \%$ \\
\hline Entre 30 e 49 anos & 45 & $42,5 \%$ & 51 & $57,3 \%$ \\
\hline Mais de 50 anos & 5 & $4,7 \%$ & 4 & $4,5 \%$ \\
\hline Total & 106 & $100,0 \%$ & 89 & $100 \%$ \\
\hline \multicolumn{5}{|l|}{ Qui-quadrado $=1,64, D F=2, P>0,050$} \\
\hline \multicolumn{5}{|l|}{ Cor da pele } \\
\hline Negras (pretas e pardas) & 87 & $82,1 \%$ & 71 & $79,8 \%$ \\
\hline Brancas (brancas e amarelas) & 19 & $17,9 \%$ & 18 & $20,2 \%$ \\
\hline Total & 108 & $100,0 \%$ & 89 & $100 \%$ \\
\hline \multicolumn{5}{|l|}{ Qui-quadrado $=0,35, D F=1, P>0,050$} \\
\hline \multicolumn{5}{|l|}{ Escolaridade } \\
\hline Ensino Fundamental incompleto & 53 & $50,0 \%$ & 31 & $34,9 \%$ \\
\hline Ensino Fundamental completo & 9 & $8,5 \%$ & 12 & $13,5 \%$ \\
\hline Ensino Médio incompleto & 19 & $17,9 \%$ & 17 & $19,1 \%$ \\
\hline Ensino Médio completo & 20 & $18,9 \%$ & 20 & $22,5 \%$ \\
\hline Ensino Superior incompleto & 1 & $0,9 \%$ & 3 & $3,4 \%$ \\
\hline Ensino Superior completo & 4 & $3,8 \%$ & 6 & $6,7 \%$ \\
\hline Total & 106 & $100,0 \%$ & 89 & $100 \%$ \\
\hline \multicolumn{5}{|l|}{ Qui-quadrado $=4,297, D F=5, P>0,050$} \\
\hline \multicolumn{5}{|l|}{ Filhos fora da prisão } \\
\hline Não & 24 & $22,6 \%$ & 22 & $24,7 \%$ \\
\hline $\operatorname{sim}$ & 82 & $77,4 \%$ & 67 & $75,3 \%$ \\
\hline Total & 106 & $100,0 \%$ & 89 & $100 \%$ \\
\hline Qui-quadrado $=0,251, D F=1, P>0,050$ & & & & \\
\hline
\end{tabular}

\section{Trajetórias e dinâmicas criminais}

A sociologia norte-americana se dedica cada vez mais a entender como o superencarceramento de homens jovens, negros e residentes de áreas periféricas aumenta o contato indireto das mulheres com as prisões. Por um lado, o fenômeno pode ser explicado em face das visitas que elas realizam aos parentes. Por outro, a questão está na vivência direta das engrenagens do sistema penal que, em razão da vigilância policial, as tornam suspeitas preferenciais quando um crime é registrado ou investigado (Melander, 2020).

Nossos dados corroboram ambas as hipóteses: 66\% das entrevistadas indicaram ter tido algum parente preso em algum momento de sua vida, em especial irmãos e companheiros. Ou seja, familiares de presos tendem a ser criminalizados pelo 


\section{GRÁFICO 1}

CATEGORIAS DE RAÇA E ESCOLARIDADE COM MAIOR INCIDÊNCIA

ENTRE O GRUPO ENTREVISTADO E OS GRUPOS DE MULHERES E HOMENS PRESOS NO PAÍS

90

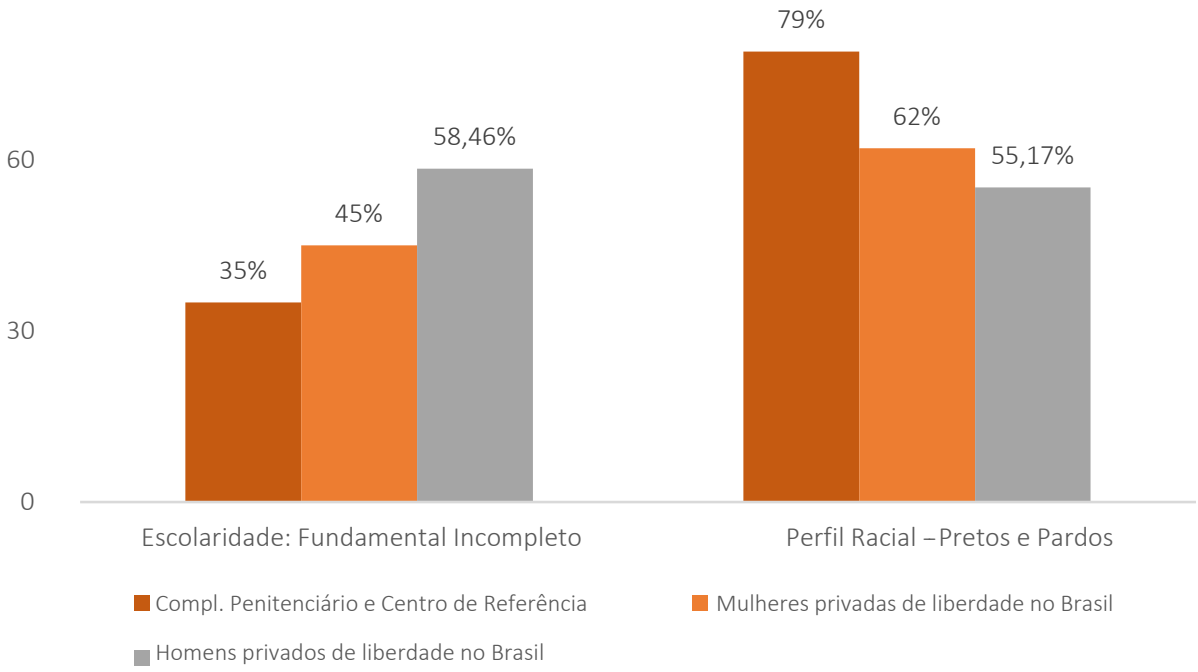

Fonte: Produzido a partir dos dados da pesquisa e dos dados do Infopen (2018).

2. Para testar esse argumento com maior profundidade, foi feito um teste de correlação entre a mulher declarar-se reincidente e dizer que o companheiro estava preso e não foi encontrada associação estatisticamente significativa. sistema de Justiça Criminal, já que são vistos como criminosos potenciais (Carneiro, 2013; Silvestre, 2012). Chamamos atenção, porém, a outra parcela das custodiadas: $34 \%$ destacaram não ter familiares que já experienciaram a privação de liberdade, não sendo possível ignorar que esse conjunto constitui um número significativo dentre as estudadas. Dito de outro modo, em alguma medida, esse dado ajuda a desconstruir a perspectiva de que as mulheres apenas têm contato com o cárcere em razão de vivências relacionadas a outros parentes, sobretudo, seus parceiros. Muitas não tiveram familiares custodiados, inexistindo, pois, uma relação determinística entre a trajetória criminal da mulher e a do esposo privado de liberdade ${ }^{2}$.

A despeito disso, como já destacado, a explosão da quantidade de mulheres privadas de liberdade relacionadas ao tráfico de drogas é explicada por grande parte da literatura e pelos operadores do sistema de Justiça Criminal como consequência direta do "amor bandido" (Helpes, 2014; Ribeiro \& Lopes, 2019). O afeto obrigaria as mulheres a transportar a droga aos seus companheiros privados de liberdade, momento em que seriam presas em flagrante (Varella, 2017). As forçariam ainda a assumirem posição de distribuidoras nas redes criminais em razão da prisão do parceiro (Diniz, 2015; Queiroz, 2015). Nossos dados, porém, nos indicaram que esse enquadramento não é suficiente para entender as dinâmicas femininas no tráfico de drogas, em reforço a algumas outras pesquisas sobre o tema (Carneiro, 2015; Barcinski, 2009). 
Embora parte das entrevistadas tenha indicado que, normalmente, as mulheres começam a participar de atividades criminosas por influência masculina $(58,8 \%)$, um número substantivo delas afirmou o contrário (41,2\%). Ao serem questionadas diretamente se tinham entrado nas atividades do tráfico em decorrência de seus relacionamentos com homens, apenas $23,5 \%$ forneceram uma resposta positiva. Rosa, que cumpria pena no Centro de Referência à Gestante Privada de Liberdade, foi uma das mulheres que afirmou ter entrado no mercado de drogas em razão do marido, destacando que os papéis de gênero tradicionais, que colocam a mulher como submissa ao homem, colaboram para esse impulsionamento. No entanto, ela mesma reforçou que a decisão final de se envolver ou não no crime é da mulher.

Entrevistada - Ah, porque, tipo assim, a mulher é submissa. Ela fica submissa ao homem. Homem manda e dá, às vezes, muito medo também. A mulher sempre fica submissa ao homem. Não adianta, eles... Esse jeito deles, machista de ser, são terríveis. O pai dos meus filhos, nó! Eu já levei droga no presídio. Ainda bem que eu não "rodei, tá!" O pai dos meus filhos!

Pesquisadora - E... Quase que você cai por causa disso?

Entrevistada - Não caí por causa dele, caí por causa de mim mesma [risos]. Não, toda vez que eu estava na Igreja, ele me perturbava, me perturbava para eu sair da Igreja. Está vendo como maldito o homem é? Depois que ele... Depois que o Satanás me colocou para fora da Igreja, aí eu tive que buscar meus recursos (Rosa, custodiada do Centro de Referência à Gestante Privada de Liberdade, entrevistada para a pesquisa).

Observamos, com base em nossos dados quantitativos, que, em termos genéricos, as custodiadas afirmam que os homens influenciariam a entrada das mulheres nas redes ilegais de drogas, mas, em termos das histórias individuais, essa narrativa é relativizada. As mulheres reconheceram o papel dos homens, ou como exemplo ou como parceiro nas redes ilegais, mas não renunciam ao poder de agência sobre as suas trajetórias. Maria, por exemplo, teria se inspirado na atuação do irmão mais velho, "o dono da favela". Ele conseguia "dinheiro fácil" e, para seguir o mesmo caminho, ela entrou para outra rede, que não a do irmão, de forma a marcar sua independência. Já Alessandra nos contou o seguinte:

Pesquisadora: Quando você se envolveu foi por causa de algum homem também?

Entrevistada: Por causa dele, porque ele tava com mandado de prisão, então ao invés dele ir fazer as coisas que ele tinha que fazer, eu coloquei o peito na frente e falei que pode deixar que eu fazia. Aí teve uma certa época que eu falei: "Nós tem que parar". Aí ele começou a trabalhar... (Alessandra, custodiada do Complexo Penitenciário Estevão Pinto, entrevistada para a pesquisa). 
Ao perguntarmos às mulheres os fatores que as levaram a atuar de modo mais perene em dinâmicas do tráfico, se sobressaíram como motivos o sustento (27,72\%), seguido daquelas que indicaram razões diversas às listadas pelo questionário $(17,8 \%)$, como desilusão amorosa, pouca maturidade, falta de sabedoria e busca de adrenalina. Outras razões foram também apontadas, como querer gastar o dinheiro angariado consigo mesmas (10,9\%) e manter o vício em drogas $(16,8 \%)$. Vale destacar, ainda, aquelas que disseram não vender, mas morar com alguém que era responsável pela mercadoria $(17,8 \%)$, o que parece indicar a existência de uma política criminal que criminaliza sistematicamente familiares de traficantes de drogas (Carneiro, 2015).

Qualquer que seja o ângulo de análise, rompe-se, com base nessas respostas, com uma narrativa monolítica vigente, centrada na submissão das mulheres em relação aos homens no mundo do crime. A despeito da dispersão das respostas, é possível observar a centralidade da questão financeira na maioria das justificativas acionadas para o envolvimento com o tráfico. Nesta direção, Cortina (2015) indicou que o ingresso das mulheres no tráfico de drogas precisa ser entendido como um efeito da feminização da pobreza. Situações típicas desse fenômeno são aquelas em que as mulheres, conforme a condição social de gênero feminino, ficam responsáveis pelos filhos. E, dado o contexto de precariedade econômica em que vivem, veem aumentar as dificuldades financeiras com o fim do relacionamento amoroso/sexual. Como muitas vezes não dispõem de outras pessoas para dividir o sustento do lar, as mulheres de periferia precisam se submeter a trabalhos precários e de baixa remuneração e, não raramente, completar e renda com atividades ilegais. Laura ressaltou sua trajetória inicial de vida como dona de casa e esposa dedicada, mãe de quatro filhos, sobre os quais fez questão de dizer:

\footnotetext{
Gostaria de ressaltar, que meus filhos não são filhos de cada um, são filhos do primeiro cara que eu namorei e casei com ele, que ele mesmo não valia nada e abandonou eu e os meus meninos. Eu toda a vida trabalhei e cuidei dos meus filhos sozinha (Laura, custodiada do Complexo Penitenciário Estevão Pinto, entrevistada para a pesquisa).
}

Uma vez sozinha com os filhos, acabou por se enveredar na atividade de venda de drogas ilícitas: "eu falei assim: 'Cansei! Eu preciso comprar um lugar para morar, eu preciso comprar um carro para andar, eu não aguento mais sofrer, não aguento'”. Essa foi a realidade mais comum dentre as nossas entrevistadas: apenas $26 \%$ alegaram não ter ocupação ou citaram as atividades criminais como única fonte de renda antes da prisão. Todas as demais apontaram outras medidas laborais, com destaque para trabalhos desenvolvidos no comércio (30\%), no setor de beleza (10\%), no 
âmbito da saúde (9\%) e como empregadas domésticas (6\%). Outras 14\% disseram atuar com "bicos" ou como "autônomas".

Ou seja, às mulheres pobres e negras são destinados serviços precários, com baixa remuneração, gerando opressões sociais e econômicas (Gonzalez, 2020; hooks, 2020). Não obstante, $72,6 \%$ das entrevistadas apontaram que, ou ajudavam a sustentar a casa, ou arcavam totalmente com as despesas domésticas antes do aprisionamento. Isto é, embora não necessariamente justificassem seu envolvimento com o tráfico em razão da manutenção do lar, a grande maioria das custodiadas com quem conversamos salientou o seu papel de centralidade na subsistência da família. Uma delas, Rogéria, contou como a busca por melhores condições financeiras a motivou a entrar nas redes de tráfico de drogas.

\footnotetext{
Pesquisadora - E me conta uma coisa, Rogéria, muita gente fala que as mulheres acabam entrando no tráfico por causa dos maridos, dos irmãos, você acha que isso é verdade?

Entrevistada - Olha, a maioria aí é, mas eu, particularmente, eu entrei por minha opinião mesmo, eu entrei pelo meu sofrimento mesmo. Porque eu cansei mesmo, se eu te mostrar a foto, o jeito que eu trabalhava.

Pesquisadora - Por quê?

Entrevistada - Porque eu trabalhava, trabalhava e eu não conseguia, eu não conseguia, entendeu? Se eu falar com você eu não tenho culpa em reclamar da comida, eu passava necessidade e não era por falta de trabalhar, porque na minha família todo mundo trabalha desde o dia que nasce, todo mundo trabalha muito, por toda a vida eu trabalhei muito, eu carregava e descarregava caminhão, minhas mãos viviam pingando sangue. De todo o jeito que você pensar, eu não tenho medo. Hoje eu tenho um braço só, mas eu não tenho medo de trabalho (Rogéria, custodiada do Complexo Penitenciário Estevão Pinto, entrevistada para a pesquisa)
}

Ao analisar os dados estatísticos à luz das entrevistas qualitativas, podemos questionar se respostas como "se sustentar", "ambição" e "gastos pessoais" têm diferenças tão marcadas como o survey pareceu indicar. A entrevistada Vera disse que o marido era "trabalhador", mas sua atuação como pedreiro e pintor não era suficiente para cobrir todas as despesas da família. Ela, por sua vez, não podia sair de casa para trabalhar e deixar os dois filhos pequenos sozinhos. Em mais uma demonstração de como gênero e classe se intercruzam nas trajetórias dessas mulheres, decidiu se engajar no tráfico, atividade que exercia de casa, para adquirir "coisas que ele (o marido) não podia comprar". Ao ser perguntada sobre o que precisava ser consumido, ela citou itens de sobrevivência e não artigos considerados "supérfluos". 
Entrevistada: Exemplo, tem... é... ele fazia as compras (verdura, carne, gás, as coisas de comer, higiene). Mas, exemplo, faltava pra pagar uma conta de telefone, a conta de luz, a conta de água... aí ficava atrasando... aí tipo assim, eu não estava me sentindo bem e ele de uma certa forma começou a jogar isso na minha cara (Vera, custodiada do Complexo Penitenciário Estevão Pinto, entrevistada para a pesquisa).

Ideias como "ostentação" ou "gastos pessoais" podem estar intrinsecamente relacionadas a confortos básicos da vida urbana, numa tentativa de reproduzir padrões de vida da classe média. A entrevistada Fernanda, também do Complexo Penitenciário Estevão Pinto, disse ter ingressado na rede "por necessidade". Depois explicou que precisava comprar fraldas e sustentar os filhos, ao que adicionou: "porque mulher é muito interessante, quer uma roupa boa, quer um sapato bom e querendo ou não a vida do crime é uma coisa bem mais fácil de arrumar dinheiro" (Fernanda, custodiada do Complexo Penitenciário Estevão Pinto, entrevistada para a pesquisa).

Outra característica manifestada nas entrevistas é a necessidade de manter uma atividade remunerada no ambiente doméstico, ao qual muitas vezes a mulher está confinada, seja por determinação do companheiro, seja por necessidade de cuidar dos filhos pequenos. Para Cortina (2015), esse tipo de imposição reforça a clássica divisão sexual do trabalho, que destina às mulheres o labor no mundo privado, normalmente não remunerado, formando os chamados "guetos femininos" nas atividades do tráfico. Assim, não é um mero detalhe o fato de $80 \%$ das entrevistadas serem mães. Em média, as presas tinham dois filhos, com o mínimo de um e o máximo de sete crianças. Como elas mesmas diziam, "são muitas bocas para se alimentar", o que muitas vezes as impulsionava a conjugar as atividades lícitas com as ilícitas, para garantir um melhor padrão de vida para si e para os filhos.

Ao que pareceu, o trânsito entre as atividades lícitas e ilícitas era em certa medida camuflado, tanto que $34,4 \%$ das mulheres pontuaram que seus familiares não sabiam que estavam envolvidas em atividade no varejo de drogas. Em muitos casos, ocorria situação diversa, já que 32,2\% das entrevistadas afirmaram que os parentes tinham conhecimento das dinâmicas criminais empreendidas, mas não participavam. Por sua vez, 18,9\% das presidiárias disseram que seus familiares sabiam e estavam envolvidos nas ações de varejo. Por fim, 17,8\% citaram não ter relação com o tráfico, mas moravam com pessoas com condutas enquadráveis como "traficantes", sendo custodiadas em razão de crimes cometidos por pessoas próximas a elas. Para além dos familiares, ao serem questionadas sobre suas redes criminais, 59,8\% das mulheres informaram ter praticado o ilícito em parceria com outra pessoa, de modo que as restantes $(40,2 \%)$ disseram traficar sozinhas. 
Em síntese, é inegável que muitas mulheres têm, em suas trajetórias, o imbricamento direto ou indireto das famílias e dos companheiros no comércio ilegal, algo também observado no trabalho de Cunha (2018). Isso, porém, pode ser contrastado com um universo considerável de mulheres que não relataram essa experiência, inexistindo um padrão homogêneo em suas trajetórias. Mais do que o envolvimento de parentes nas dinâmicas criminais, há alguma prevalência nas narrativas da função central das mulheres no sustento das famílias, em especial no que diz respeito aos filhos. E isso não pode ser desconsiderado na análise.

Dito de outro modo, o enredamento feminino no varejo de drogas atravessa questões ligadas às redes familiares e aos relacionamentos afetivos, mas não necessariamente na forma de "má influência" ou de mera subordinação. É a partir das estratégias mobilizadas por essas mulheres pobres para garantir o sustento financeiro das famílias e das maneiras como a vigilância policial recai sobre elas que precisamos olhar para o fenômeno da criminalidade e do aprisionamento feminino (Carneiro, 2015). Nesse sentido, nossos dados reforçam o argumento de Vera Telles (2013) acerca da transitividade entre o formal e o informal, legal e ilegal, centro das dinâmicas de periferias urbanas. Para sobreviver, as mulheres acionam tanto a renda decorrente de trabalhos legais como aquela advinda de atividades informais, conjugada às provenientes de ocupações no tráfico de drogas.

Diante disso, cabe-nos entender como essas diferentes trajetórias foram enredadas pelo sistema de Justiça Criminal. Para tanto, procuramos descrever como ocorreram as detenções, o que será analisado na próxima seção.

\section{Características das detenções}

Para apreender como as mulheres acusadas ou condenadas por tráfico de drogas foram capturadas pelo sistema de Justiça Criminal, incluímos em nossos questionários algumas perguntas sobre suas detenções. Um primeiro aspecto a ser depreendido dos dados quantitativos diz respeito à experiência das mulheres com a vida carcerária, já que o grupo das presas por tráfico de drogas se divide quase homogeneamente entre as rés primárias $(49,1 \%)$ e as com passagens anteriores pela prisão (50,9\%). Entre essas últimas, a média de vezes que uma entrevistada disse ter sido previamente presa foi de três vezes, com o mínimo de duas detenções e o máximo de dezoito. A maioria delas - um total de 36,8\% - tinha sido privada de liberdade antes por tráfico, mesmo que a conduta tenha sido cometida em associação com outros crimes, como roubo e homicídio. Apenas 15\% das mulheres indicaram ter sido presas anteriormente por delito alheio ao varejo de drogas. 
3. Utilizamos a conversão proposta pelo Instituto Igarapé, em 2015, para construir a tabela, qual seja: i. Pino de cocaína = 0,5 gramas;

ii. Pedra de crack = 0,3 gramas; iii. Cigarro ou baseado de maconha = 0,1 grama.

4. Como se pode observar, os valores médios são flutuantes em face das grandes diferenças entre o mínimo e o máximo de droga. Esse dado nos ajuda a reforçar a hipótese de que as mulheres se enquadram em diferentes perfis criminais, não havendo um tipo de conduta homogêneo entre elas.

5. Valor correspondente a 4,7 vezes o valor do salário mínimo vigente no momento da pesquisa, que era de $\mathrm{R} \$ 950,00$
As mulheres sublinharam diferenças consideráveis sobre a quantidade de drogas ou de dinheiro com que foram apreendidas, o que espelha posicionamentos e atuações diferentes no tráfico. Cabe destacar que 35\% delas pontuaram não portar qualquer tipo de droga durante a prisão. Ou essas mulheres tiveram receio em expor algo que as incriminasse diante da pesquisa ou foram mesmo presas sem que portassem qualquer substância. Dentre as que apontaram carregar consigo algum tipo de droga, a Tabela 2 resume o quantitativo de substâncias apreendidas, a quantidade mínima, a máxima e a média.

TABELA 2

PORTE DE DROGA DURANTE A PRISÃO

\begin{tabular}{lccccc}
\hline $\begin{array}{c}\text { Tipo de } \\
\text { droga }\end{array}$ & $\begin{array}{c}\text { Total de } \\
\text { mulheres presas }^{a}\end{array}$ & $\begin{array}{c}\text { Mínimo } \\
\text { apreendido }(\mathrm{kg})\end{array}$ & $\begin{array}{c}\text { Máximo } \\
\text { apreendido }(\mathrm{kg})\end{array}$ & $\begin{array}{c}\text { Média } \\
\text { apreendida }(\mathrm{kg})\end{array}$ & $\begin{array}{c}\text { Desvio padrão } \\
\text { Maconha }\end{array}$ \\
Cocaína & 23 & $0,01^{b}$ & 97 & 14 & 25,65 \\
Crack & 22 & $0,01^{c}$ & 4.470 & 180 & $\mathbf{8 5 9}$ \\
\hline
\end{tabular}

a. Não foi possível obter informações para quatro mulheres.

b. Sem informação para 5 casos.

c. Sem informação para 5 casos.

d. Sem informação para 15 casos

Fonte: Produzido a partir dos dados da pesquisa.

A pergunta do survey a respeito das quantidades de drogas apreendidas foi aberta, de forma que as respostas usaram medições diferentes, como cigarros ou gramas no caso de maconha, pinos ou quilos no caso de cocaína. Portanto, para construir a Tabela 2 fizemos a conversão das informações obtidas conforme a proposta do

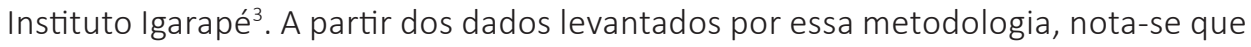
foram apreendidos, em média, 14 quilos de maconha, 180 quilos de cocaína e 0,5 quilos de $\mathrm{crack}^{4}$. Apenas $7 \%$ das mulheres portavam, concomitantemente, os três tipos de drogas durante sua prisão. Tamanha dispersão é também visível na quantidade de dinheiro que elas traziam no momento da prisão. Cerca de $27 \%$ portavam algum recurso financeiro, mas, no geral, em pequena quantidade. Duas presas indicaram possuir apenas dez reais, a despeito de outra ter mencionado levar consigo $R \$ 4.500,00^{5}$.

Segundo Sena (2015), outra característica do mercado de drogas operado por muIheres é a ausência de arma de fogo. Esse padrão foi encontrado entre as entrevistadas: $12,7 \%$ delas portavam armas de fogo durante sua detenção, ao passo que apenas $5 \%$ detinham as chamadas armas brancas. Somente 16 mulheres portavam ambos os tipos de armamento, bem como apenas 14 dispunham de drogas e armas simultaneamente. 
so, nossa pesquisa indicou que mais de um terço das mulheres $(36,8 \%)$ foi presa em casa. Este padrão contrasta com os homens privados de liberdade pelo mesmo crime, os quais, em sua maioria, são presos em via pública. Juliana de Oliveira Carlos (2015) constatou que, em São Paulo, as mulheres têm duas vezes mais possibilidade de serem presas em domicílio e dez vezes mais de serem autuadas nas portas das unidades prisionais, em comparação aos locais de flagrante dos homens. Elena, interna do Complexo Penitenciário Estevão Pinto, além de narrar a forma como ocorreu sua detenção, destacou que não tinha qualquer droga consigo e, mesmo assim, foi presa.

\begin{abstract}
Entrevistada - A minha abordagem foi pela polícia civil, eu estava dormindo em casa e aí estava eu e meu namorado, meu ex-namorado, e eles entraram invadiram mesmo. Uns vinte policiais, mais ou menos, todos armados, encapuzados, eu nem sabia se era polícia o que era, porque era cinco horas da manhã. E aí abordaram a gente, me algemou e colocou na sala e levou ele para a cozinha e ficou lá querendo saber onde estava droga, onde estava dinheiro, vasculharam minha casa toda, foi um dia difícil. Eu apanhei, assim não fisicamente, eles puxaram muito meu cabelo, porque não tem como detectar, eu fui muito... Eu tive muito medo assim, porque tinha muitas armas apontada para o meu lado, ele apanhou muito também, mas eu não vi, então foi um dia muito difícil. Eles entraram na minha casa cinco horas da manhã, eu fui para a delegacia umas nove, dez horas da manhã, então eles ficaram muito tempo com a gente lá torturando, querendo saber.

Pesquisadora - E eles acharam droga na sua casa?

Entrevistada - Não (Elena, custodiada do Complexo Penitenciário Estevão Pinto, entrevistada para a pesquisa).
\end{abstract}

O elevado número de entrevistadas que alegou ter sido presa em casa suscita duas hipóteses, não necessariamente excludentes entre si. A primeira é a de que, como mencionado, algumas mulheres efetivamente desenvolvem a atividade a partir do ambiente doméstico, de forma a conjugá-la com obrigações relacionadas, por exemplo, ao cuidado dos filhos. Nessa linha, teríamos a feminilização da pobreza empurrando-as ao comércio ilegal (Cortina, 2015), combinada com o lugar tradicionalmente atribuído à mulher (o âmbito doméstico), o que as permitiria realizar a atividade sem despertarem maiores suspeitas, como pressupõe o conceito de funcionalidade moral (Sena, 2015).

A segunda hipótese está mais associada ao funcionamento da Justiça Criminal, baseada no policiamento em áreas periféricas (Cunha, 2018), cujos alvos preferenciais são indivíduos relacionados a pessoas presas (Carneiro, 2015) ou sob suspeita em razão de sua cor (Gonzalez \& Hasenbalg, 1982). Nesse caso, teríamos o estigma das 
áreas pobres como determinante do crime (Gonzalez, 2020), além da criminalização de familiares de presos (Silvestre, 2012), o que reverberaria na prisão dos parentes de "líderes do tráfico", mesmo que esses sujeitos não estejam envolvidos, direta ou indiretamente, com o mercado ilegal (Carlos, 2015). A entrevistada Gabriela, ao contar sobre sua prisão, evidenciou uma das formas como o encarceramento pode ser o resultado do aumento da vigilância sobre as pessoas que circundam alguém que já está ou esteve privado de liberdade. Ela alegou ter sido capturada a partir de escutas telefônicas da polícia sobre o namorado, que era egresso do sistema prisional.

\begin{abstract}
Entrevistada: É o contato que ele tinha comigo, ele saia comigo andava no meu carro e eu andava no dele, então eles colocaram assim, eles usaram muitas "sinopses" mesmo para poder falar, as vezes eu falava: "Ah eu estou indo na padaria" e eles entendiam que eu estava indo... entendeu? Fazer algo que era ilícito no caso (Gabriela, custodiada do Complexo Penitenciário Estevão Pinto, entrevistada para a pesquisa).
\end{abstract}

A hipótese da prisão de familiares de pessoas presas ou egressas do sistema prisional a partir do aumento da vigilância sobre as mulheres tem sido amplamente sustentada pela literatura relativa à seletividade penal (Valença \& Castro, 2018). Suas ideias são de fundamental importância para entender o processamento criminal das mulheres posteriormente às suas detenções, como veremos na próxima seção.

\title{
Perfis dos julgamentos
}

De acordo com o nosso survey, ao serem perguntadas sobre quais foram as pessoas que figuraram como testemunhas em seus processos judiciais, 55,6\% das entrevistadas citaram apenas os policiais que efetuaram as suas prisões. Por seu turno, $33,1 \%$ indicaram que, além dos agentes de segurança, vizinhos e parentes foram testemunhas. Apenas 5,1\% delas não apontaram o envolvimento de policiais na tramitação de seus casos no sistema de Justiça. Esse padrão tem sido constatado nas pesquisas sobre funcionamento do sistema de Justiça Criminal, as quais sublinharam que a palavra do policial responsável pelo flagrante tem o status de verdade real, viabilizando a condenação inconteste daquele sujeito (Jesus, 2020).

A narrativa policial ajuda até mesmo a corroborar a visão de que as mulheres cometem crimes em razão do "amor bandido" (Helpes, 2014), mesmo que muitas digam não só o contrário, como também narrem a não participação em atividades ilegais. Conforme o relato a seguir, parece existir, ao mesmo tempo, uma dissociação entre as investigações policiais que levaram ao convencimento judicial e a descrição das mulheres sobre suas inserções nas redes criminais. 
Na pirâmide que eles (os policiais) fizeram (no inquérito), eles fizeram a divisão de três partes, a primeira, a segunda e a terceira. As mulheres ficaram na terceira parte, que eram das companheiras dos traficantes que ajudavam, gastavam o dinheiro, ajudavam a esconder. Tipo, eu sabia que ele era um traficante, então eu ajudava ele de uma certa forma por não denunciar, por não entregar para a polícia, por usar o dinheiro, por morar e usufruir (Elena, custodiada do Complexo Penitenciário Estevão Pinto, entrevistada para a pesquisa).

A entrevistada Elena, apesar de negar o envolvimento com os negócios do tráfico, demonstrou certo conformismo com a decisão judicial, posto que reconheceu que não denunciava e que usufruía do dinheiro auferido no tráfico. Não contestou, portanto, a decisão judicial, padrão comum a outras das entrevistadas. Apesar de essa narrativa afirmar o lugar da mulher como culpada, mais pela passividade do que por atos criminais em si, ao observar as condenações resultantes desses processos, notamos que as penas aplicadas são altas, com o mínimo de um ano e meio e o máximo de 33,6 anos, com a média de 9 anos. A maioria delas $(59,9 \%)$ recebeu penas entre cinco e nove anos de prisão, ao passo que $27 \%$ foram condenadas a penas entre 10 e 14 anos.

Embora em número menor, chama atenção o fato de que 7,5\% das mulheres tiveram penas de até quatro anos, o que, conforme a legislação penal brasileira, poderia gerar a conversão da privação de liberdade em outros tipos de sanção, como penas restritivas de direitos. Ou seja, há mulheres presas por tráfico que poderiam estar em liberdade. Ao cruzar os tempos de pena com outras características criminais relatadas pelas mulheres, não há um padrão que indique associação direta entre as dinâmicas narradas e suas condenações (Tabela 3).

A maioria das interlocutoras (74,5\%) alegou ter sido condenada apenas pelo crime de tráfico de drogas, ao passo que 19,8\% disseram ter sido presas por tráfico e outro crime não listado em nosso survey. Do ponto de vista estatístico, o tipo de crime pelo qual a mulher foi condenada está associado ao tempo médio de prisão que ela precisará cumprir. Aquelas sentenciadas somente por tráfico de drogas receberam, em média, oito anos de prisão, o que contrasta diretamente com as entrevistadas julgadas também por homicídio (22,5 anos, em média), por roubo (10,3 anos, em média) ou por algum outro crime (12,7 anos, em média).

A Tabela 3 indica que não há diferença estatisticamente significativa nos anos de condenação entre as mulheres com passagem anterior pelo sistema prisional em comparação às que informaram estar em contato com o cárcere pela primeira vez. 
TABELA 3

MÉDIAS DE TEMPOS DE PENAS DAS PRESAS CONDENADAS

do Centro de Referência À Gestante Privada de Liberdade e do Complexo

Penitenciário ESTEVÃo PINTO, POR CONDENAÇÕES ANTERIORES, ASSOCIAÇÕES PARA O TRÁFICO E COMETIMENTO DE OUTROS CRIMES ${ }^{a}$

\begin{tabular}{|c|c|c|c|c|c|c|}
\hline Padrão & $\mathrm{N}$ & Mínimo & Máximo & Mediana & Média & Desvio \\
\hline \multicolumn{7}{|l|}{ Quantas vezes você já foi presa? } \\
\hline É a primeira vez & 43 & 1,7 & 27,3 & 9,0 & 9,3 & 4,2 \\
\hline Mais de uma vez & 50 & 2,5 & 33,6 & 7,5 & 9,4 & 6,5 \\
\hline \multicolumn{7}{|l|}{ Anova $=0,000, D F=91, p>0,050$} \\
\hline \multicolumn{7}{|l|}{ Por qual delito você está presa? } \\
\hline Tráfico de drogas (33) & 70 & 1,7 & 19,0 & 7,5 & 8,0 & 3,1 \\
\hline Tráfico de drogas (33), Homicídio (121) & 2 & 12,0 & 33,0 & 22,5 & 22,5 & 14,8 \\
\hline Tráfico de drogas (33), Outro & 19 & 2,5 & 33,6 & 10,0 & 12,7 & 8,2 \\
\hline Tráfico de drogas (33), Roubo (157) & 2 & 6,2 & 14,5 & 10,3 & 10,3 & 5,9 \\
\hline Anova $=9,526, D F=91, p<0,000$ & 93 & 1,7 & 33,6 & 8,0 & 9,4 & 5,5 \\
\hline \multicolumn{7}{|l|}{ Como você cometeu o crime? } \\
\hline Cometeu sozinha & 39 & 2,5 & 33,0 & 7,0 & 8,2 & 4,8 \\
\hline Cometeu com alguém & 51 & 1,7 & 33,6 & 9,0 & 10,2 & 6,0 \\
\hline Anova $=3,012, D F=89, p>0,050$ & 90 & 1,7 & 33,6 & 7,9 & 9,3 & 5,6 \\
\hline
\end{tabular}

a. Nove presas eram provisórias e, por isso, não responderam à questão sobre tempo de pena.

Fonte: Produzido a partir dos dados da pesquisa.

A média de pena de ambas é de nove anos. A condição de ré primária não foi, para as entrevistadas, garantia de penas mais brandas, o que gera certa revolta entre as custodiadas, como nos relatou Clara.

Entrevistada - Eu falo por mim assim, eu não aceito a minha pena sabe? Assim, hoje eu já vejo ela, que eu tenho que pagar o tempo que eu tenho que pagar, mas eu por ser réu primaria por ter residência fixa, não ter passagem nenhuma em delegacia e nem nada eu creio que meu julgamento contém muitos erros. Então meu processo está sendo revisado, estou esperando apelação que vai para a segunda instância, já tem um ano e quatro meses e eu estou no aguardo para ver se cai para eu poder ir embora desse lugar (Clara, custodiada da Complexo Penitenciário Estevão Pinto, entrevistada para a pesquisa).

A custodiada mobilizou características de sua trajetória que, legalmente, deveriam resultar em redução ou aumento da pena. No entanto, em sua avaliação, tais questões não impactaram na decisão judicial. Retomando a Tabela 3, observamos que o cometimento do crime sozinhas também não pareceu ser preditor das penas, embora, legalmente, ter praticado o delito com outras pessoas possa aumentá-la, con- 
forme disposto no artigo 35 do Código Penal. Ainda que as presas que realizaram o crime acompanhadas tenham recebido pena um pouco maior do que aquelas que o desenvolveram sozinhas (em média 10,2 anos versus 8,2 anos, respectivamente), essa diferença não é estatisticamente significativa.

Sobre esse ponto, Sena (2015) indicou existir diferenças significativas entre as dinâmicas de comércio de entorpecentes conduzidas por mulheres sozinhas e em parceria com outros indivíduos. A sobrevivência feminina no comércio de bocas, aquele realizado por pessoas de baixa renda, é estruturada a partir de "agentes cujas conexões estabelecem vínculos de subordinação relativos às posições hierárquicas das ocupações desempenhadas" (Sena, 2015: 57). Como estão diretamente vinculadas a outros sujeitos no network criminal, as mulheres pobres tendem a revender a mercadoria com a ajuda de alguém para garantir proteção e segurança. Situação distinta é encontrada no comércio identificado como "empreendedor", em que as mulheres atuam sozinhas, por já estarem protegidas de clientes desonestos ou agressivos, "devido às restrições de reputação de classe atribuídas a essa droga" (Sena, 2015: 56).

Em outras palavras, o cometimento do delito em conjunto com outras pessoas pode ser uma relevante variável para entender as dinâmicas criminais. Entretanto, os relatos femininos sobre as práticas conduzidas, cruzados com as penas recebidas, não pareceram indicar que os órgãos públicos levem essas diferenças em consideração. Ou seja, assim como a literatura da área, o sistema de Justiça Criminal parece não ser capaz de processar as diferentes formas de pertencimento das mulheres às redes criminais. Características das trajetórias relatadas por elas, que incluem prisões anteriores, associações de outras pessoas para o cometimento do crime e quantidade de drogas envolvida pareceram não se relacionar com as prisões e penas aplicadas. Há indicativos, ainda, de que esse sistema tende a compreendê-las a partir de uma imagem homogeneizada (Ribeiro \& Lopes, 2019), que encontra na literatura da área um espelho de mulheres orientadas por seus companheiros (Helpes, 2014).

Esse reflexo não foi necessariamente traduzido nas narrativas das mulheres com quem conversamos. Em algumas situações, elas até acionaram a narrativa do "amor bandido" como justificativa para a entrada no crime, mas reforçaram que a escolha final é da própria mulher. Os policiais, por sua vez, tendem a vigiá-las com enorme intensidade, especialmente, quando possuem um companheiro nas redes de revenda de mercadoria ilegal. As narrativas desses agentes são incontestáveis aos olhos da Justiça (Jesus, 2020). Nesse caso, elas poderiam até acionar a submissão aos homens como uma "funcionalidade moral" (Sena, 2015) para garantir menores punições. Todavia, como nos relataram as entrevistadas, isso parece não funcionar, já que suas punições 
não são suavizadas nem mesmo diante de requisitos legais, como a primariedade ou a ausência de outras pessoas na prática do delito. O que vemos é um sistema de justiça bastante empenhado em puni-las com rigor pela prática do tráfico de drogas.

\section{Considerações finais}

O nosso objetivo neste artigo foi compreender as consonâncias/dissonâncias entre o apontado por mulheres presas por tráfico de drogas sobre as dinâmicas criminais por elas empreendidas vis-à-vis o enquadramento dado a essas práticas pela literatura especializada e pelo sistema de Justiça Criminal. Em boa medida, pareceu existir uma convergência entre as narrativas. Entretanto, tais perspectivas parecem não conseguir abarcar a multiplicidade de experiências dessas mulheres.

Ao analisarmos as trajetórias das participantes da pesquisa, evidenciadas tanto na fase quantitativa quanto na qualitativa, notamos que, nas diversas dimensões discutidas, não há uma tendência única. O número de presas pela primeira vez foi quase o mesmo daquelas já encarceradas anteriormente. Embora a maioria das mulheres tenha afirmado que algum de seus familiares já foi privado de liberdade, um número grande não teve essa experiência. A impossibilidade de construção de uma narrativa única se estendeu ainda a outras características das dinâmicas relatadas, desde as motivações ao engajamento no mercado ilegal de drogas até o envolvimento de outros indivíduos nas práticas delituosas. A mesma conclusão se pode extrair das condições das prisões das mulheres: há uma grande dispersão nos dados relativos à quantidade de drogas, de dinheiro e de armas apreendidos.

A despeito da diversidade de relatos, o tempo de condenação dessas mulheres pareceu não espelhar as características dos crimes por elas narrados. Ser ou não ré primária, bem como cometer o crime sozinha ou em associação a terceiros, não foram preditores das penas. Para entender esse descolamento, encontramos nas entrevistas qualitativas indícios de que as condenações tenderam a refletir mais uma compreensão geral e monolítica dos atores do sistema de justiça a respeito da criminalidade feminina ao invés de espelhar os casos individuais.

A percepção majoritária entre os operadores da Justiça Criminal pareceu convergir com ideias que dominam a literatura da área. Para ambos, haveria uma associação intrínseca entre a criminalidade feminina, os relacionamentos familiares e os afetos das mulheres envolvidas com tráfico de drogas. No entanto, ao analisar os relatos das trajetórias individuais das entrevistadas, essa narrativa se mostra insuficiente para explicar a heterogeneidade das dinâmicas estabelecidas pelas mulheres. Apesar disso, não deixa de ser notável que esse enquadramento, com o qual as custo- 
diadas em sua maioria demonstrou não se identificar, é repetido por elas quando são realizadas perguntas mais gerais sobre criminalidade feminina. Não à toa, muitas disseram que as mulheres em geral se envolvem em dinâmicas delituosas em face do padrão de ação masculino.

Essa repetição demonstra como a ideia de que o "amor bandido é chave de cadeia" é forte entre atores do universo penal - sejam eles atores da Segurança Pública, operadores do direito, sejam as próprias mulheres privadas de liberdade. Por isso, não conseguem separar essa ideia homogeneizante dos casos individuais sobre os quais são instados a agir. Já as mulheres que vivenciam "na pele" o "peso do cárcere" têm narrativas bastante elaboradas sobre como o mundo legal e ilegal se inter-relacionam em suas próprias histórias.

\section{Referências}

ADORNO, Sergio; DIAS, Camila Nunes. Cronologia dos "Ataques de 2006" e a nova configuração de poder nas prisões na última década. Revista Brasileira de Segurança Pública, v. 2, p. 118-132, 2016.

ALCOFF, Linda Martin; POTTER, Elizabeth. Introduction. In: . Feminist epistemologies, New York: Routledge, 1993.

ANGOTTI, Bruna. Entre as leis da ciência, do Estado e de Deus: o surgimento dos presídios femininos no Brasil. São Paulo: Ibccrim, 2012.

ANGOTTI, Bruna; SALLA, Fernando. Apontamentos para uma história dos presídios de mulheres no Brasil. Revista de História de las Prisiones, v. 6, p. 7-23, 2018.

AZEVEDO, Rodrigo Ghiringhelli; SINHORETTO, Jacqueline. O sistema de justiça criminal na perspectiva da antropologia e da sociologia. Revista Brasileira de Informação Bibliográfica em Ciências Sociais (BIB), n. 84, v. 2, p. 188-215, 2018.

BARCINSKI, Mariana. Centralidade de gênero no processo de construção da identidade de mulheres envolvidas na rede do tráfico de drogas. Ciências Saúde Coletiva [online], v. 14, n. 5, p.1843-1853, 2009. Disponível em: <https://doi.org/10.1590/ S1413-81232009000500026>.

CARLOS, Juliana de Oliveira. Política de drogas e encarceramento em São Paulo, Brasil. London: International Drug Policy Consortium, 2015. 
CARNEIRO, Ludmila Gaudad Sardinha. Mulas, olheiras, chefas \& outros tipos: heterogeneidade nas dinâmicas de inserção e permanência de mulheres no tráfico de drogas em Brasília-DF e na cidade do México. Tese (Doutorado em Sociologia) - Universidade de Brasília, Brasília, 2015.

. Em busca dos direitos perdidos: ensaio sobre abolicionismos e feminismos. Revista Jurídica da Presidência, v. 15 n. 107, p. 605-630, 2013.

CHAVES, Luana Hordones; ARAÚJO, Isabela Cristina Alves. Gestação e maternidade em cárcere: cuidados de saúde a partir do olhar das mulheres presas em uma unidade materno-infantil. Physis: Revista de Saúde Coletiva, v. 30, n. 1, 2020.

CORTINA, Mônica Ovinski Camargo. Mulheres e tráfico de drogas: aprisionamento e criminologia feminista. Revista Estudos Feministas, v. 23, n. 3, p. 761-778, 2015.

CUNHA, Maria Ivone. Entre o bairro e a prisão: tráfico e trajectos. Lisboa: Etnográfica Press, 2018.

DAUDELIN, Jean; RATTON, José Luis. Mercados de drogas, guerra e paz no Recife. Tempo Social, v. 29, n. 2, p. 115-134, 2017.

DIAS, Camila Nunes. Da pulverização ao monopólio da violência: expansão e consolidação do Primeiro Comando da Capital (PCC) no sistema carcerário paulista. Tese (Doutorado em Sociologia) - Departamento de Sociologia, Universidade de São Paulo, São Paulo, 2011.

DINIZ, Debora. Cadeia: relato sobre mulheres. Rio de Janeiro: Editora Civilização Brasileira, 2015.

ERICSON, Sóstenes. "Desalentadas": subjetivação em dizeres sobre as mulheres que desistiram de procurar trabalho. Revista Katálysis, v. 23, n. 3, p. 707-719, 2020.

ESPINOZA, Olga. A mulher encarcerada em face do poder punitivo. São Paulo: Ibccrim, 2004.

GONÇALVES, Rosangela Teixeira; BRITO, Josiane Silva. Os acordos entre o PCC e o Estado: a disseminação do comando nas unidades femininas de São Paulo. O Público e o Privado, n. 33, p. 41-72, 2019.

GONZALEZ, Lélia. A mulher negra na sociedade brasileira: uma abordagem político-econômica. In: RIOS, Flavia; LIMA, Márcia (Orgs.). Por um feminismo afro-latinoamericano. Rio de Janeiro: Zahar Editores, 2020.

GONZALEZ, Lélia; HASENBALG, Carlos Alfredo. Lugar de negro. São Paulo: Marco Zero, 1982. 
GRILLO, Carolina Christoph; POLICARPO, Frederico; VERÍSSIMO, Marcos. A "dura" e o "desenrolo": efeitos práticos da nova Lei de Drogas no Rio de Janeiro. Revista de Sociologia e Política, v. 19, n. 40, p. 135-148, 2011.

HARAWAY, Donna, "Saberes localizados: a questão da ciência para o feminismo e o privilégio da perspectiva parcial". Cadernos Pagu, v. 5, p. 7-42, 1995.

HARDING, Sandra. Comment on Walby's against epistemological chasms: the science question in feminism revisited. Signs: Journal of Women in Culture and Society, v. 26, n. 2, p. 511-525, 2001.

HELPES, Sintia Soares. Vidas em jogo: um estudo sobre mulheres envolvidas com o tráfico de drogas. São Paulo: Ibccrim, 2014.

HIRATA, Helena. Gênero, classe e raça Interseccionalidade e consubstancialidade das relações sociais. Tempo Social, v. 26, n. 1, p. 61-73, 2014. Disponível em: <https://doi.org/10.1590/S0103-20702014000100005>.

HIRATA, Helena; KERGOAT, Danièle. Novas configurações da divisão sexual do trabaIho. Cadernos de pesquisa 37, n. 132, p. 595-609, 2007.

HOOKS, bell. O feminismo é para todo mundo: políticas arrebatadoras. 13. ed. Rio de Janeiro: Rosa dos Tempos, 2020.

KERGOAT, Danièle. Ouvriers = ouvrières? Propositions pour une articulation théorique de deux variables: sexe et classe sociale. Critiques de l'Économie Politique, v. 5, nouvelle série, p. 65-97, 1978.

JESUS, Maria Gorete Marques. Verdade policial como verdade jurídica: narrativas do tráfico de drogas no sistema de justiça. Revista Brasileira de Ciências Sociais, v. 35, n. 102, 2020.

LEMGRUBER, Julita. Cemitério dos vivos: análise sociológica de uma prisão de muIheres. 2. ed., Rio de Janeiro: Forense, 1999.

LOURENÇO, Luiz Claudio; ALVAREZ, Marco Cesar. Estudos sobre prisão: um balanço do estado da arte nas ciências sociais nos últimos vinte anos no Brasil (1997-2017). Revista Brasileira de Informação Bibliográfica em Ciências Sociais (BIB), n. 84, v. 2, p. 1-9, 2018.

MARTINO, Natália Cristina Costa. Mulheres encarceradas: cruzamento entre redes familiares e redes prisionais. São Paulo: IBCCRIM, 2019. 
MELANDER, Lisa. Keeping connected while living apart: an exploration of a prison contact maintenance program. Journal of Offender Rehabilitation, v. 59, n. 5, p. 267-284, 2020.

MINISTÉRIO DA JUSTIÇA. Relatório temático sobre as mulheres privadas de liberdade. Brasília: Departamento Penitenciário Nacional, Jun. 2017.

MIYAMOTO, Yumi; KROHLING, Aloísio. Sistema prisional brasileiro sob a perspectiva de gênero: invisibilidade e desigualdade social da mulher encarcerada. Direito, Estado e Sociedade, n. 40, p. 223-241, 2012.

PADOVANI, Natalia Corazza. Sobre casos e casamentos: afetos e "amores" através de penitenciárias femininas em São Paulo e Barcelona. Tese (Doutorado em Antropologia Social) - Instituto de Filosofia e Ciências Humanas, Universidade de Campinas, Campinas, 2015.

QUEIROZ, Maria Lucena. A abordagem feminista das relações internacionais e violações de direitos humanos no Brasil - uma discussão sobre o sistema prisional. Revista Transgressões: Ciências Criminais em Debate, v. 3, n. 2, p. 5-31, 2015.

RATTON, José Luis; GALVÃO, Clarissa. Para além da maldade, da loucura e da vitimização: agência intencional e volição em crimes violentos praticados por mulheres. Civitas - Revista de Ciências Sociais, v. 16, n. 1, p. 26-41, 2016.

RIBEIRO, Ludmila Mendonça Lopes. Análise da política penitenciária feminina do estado de Minas Gerais: o caso da Penitenciária Industrial Estevão Pinto. Dissertação (Mestrado em Administração Pública) - Fundação João Pinheiro, Belo Horizonte, 2003.

RIBEIRO, Ludmila Mendonça Lopes; LOPES, Tacyana. Justiça criminal e gênero: o fluxo do tráfico de drogas em Montes Claros, Minas Gerais, de 2009 a 2014. Dilemas - Revista de Estudos de Conflito e Controle Social, v. 12, n. 2, p. 401-426, 2019.

SCHWARCZ, Lilia. Nem preto nem branco, muito pelo contrário: cor e raça na sociabilidade brasileira. São Paulo: Companhia das Letras, 2013.

SCOTT, Joan. Gênero: uma categoria útil de análise histórica. Educação e Realidade. v. 20, n. 2, p. 71-99, 1995.

SENA, Lucia Lamounier. I love my White: mulheres no registro do tráfico ilegal de drogas. Tese (Doutorado em Ciências Sociais) - Programa de Pós-graduação em Ciências Sociais, Pontifícia Universidade Católica de Minas Gerais, Belo Horizonte, 2015. 
SILVESTRE, Giane. Dias de visita: uma sociologia da punição e das prisões. São Paulo: Alameda, 2012.

SOARES, Barbara Musumeci; ILGENFRITZ, lara. Prisioneiras: vida e violência atrás das grades. Rio de Janeiro: Garamond, 2002.

SOUZA, Luis Antonio. Francisco. As contradições do confinamento no brasil: uma breve revisão da bibliografia sobre encarceramento de mulheres. Sociedade em Debate, v. 22, n. 2, p. 127-156, 2016.

TELLES, Vera. Jogos de poder nas dobras do legal e ilegal: anotações de um percurso de pesquisa. Serviço Social e Sociedade, n. 115, p. 443-461, 2013.

VARELLA, Drauzio. Prisioneiras. São Paulo: Companhia das Letras, 2017.

VALENÇA, Manuela Abath; CASTRO, Helena Rocha C. de. Mulheres e drogas sob o cerco policial. Revista Brasileira de Ciências Criminais, n. 146, p. 483-514, 2018.

WORLD PRISON. World prison brief data. Disponível em: <https://www.prisonstudies.org/world-prison-brief-data>. Acessado em: Ago. 2020. 